\title{
Strategi Penguatan Moral Siswa di Sekolah (Study Deskriptif Tentang Penguatan Nilai Moral Siswa Melalui Program Sekolah di SDN 4 Cakranegara Mataram)
}

\author{
Deni Sutisna $^{1}$, Ashar Pajarungi Anar ${ }^{2}$, Dyah Indraswati ${ }^{3}$, \\ Nursaptini $^{4}$, Arif Widodo ${ }^{5}$ \\ PDSG FKIP Universitas Mataram, Indonesia \\ 11denisutisna@unram.ac.id, 2ashar.pajarungianar@unram.ac.id, \\ 3dyahindraswati@unram.ac.id, nursaptini@unram.ac.id, 5arifwidodo@unram.ac.id
}

\begin{abstract}
This study aims to examine how strategies to strengthen student morale through school programs. In analyzing the problem, this study used a descriptive method with observation, interview and documentation study techniques. Some of the findings obtained from the research show that students' moral strengthening strategies are implemented in several aspects; first on the vision and mission of the school where the school sets the vision and mission and goals of the school that imply the values of faith, piety and religion in order to strengthen student morale, secondly in activities both in activities within the school environment or activities outside the school environment related to activities religious values in order to increase religious value, the third application of teacher exemplary aims to provide good moral examples for students so that students learn from existing models, namely teachers, fourth on school facilities and infrastructure, fifth on school rules arranged based on vision mission and school objectives. The results of the research show that this strategy is quite successful in strengthening student morale. There are several findings that can hinder the success of the application of students' moral values, such as: the number of students who are not balanced with the number of classes, the number of teachers who are less than ideal, the utilization of facilities is not optimal, the lack of commitment of the school community, especially the lack of cooperation between parents in strengthening efforts. student morale.
\end{abstract}

Keyword: Moral, Strategy, Students And School

Abstrak : Penelitian ini bertujuan untuk mengkaji bagaimana strategi penguatan moral siswa melalui program sekolah. Dalam

AR-RIAYAH : Jurnal Pendidikan Dasar vol. 4, no. 2, 2020

IAIN Curup - Bengkulu l p ISSN 2580-362X; e ISSN 2580-3611

http://journal.iaincurup.ac.id/index.php/JPD

DOI: $10.29240 /$ jpd.v4i2.1945 | p. 173-188 
menganalisis permasalahan, penelitian ini menggunakan metode deskriptif dengan teknik observasi, wawancara dan studi dokumentasi. Beberapa temuan yang diperoleh dari penelitian bahwa strategi penguatan moral siswa diimplementasikan dalam beberapa aspek; pertama pada visi-misi sekolah di mana sekolah menyusun visi-misi dan tujuan sekolah yang menyiratkan nilai iman, takwa dan religius guna menguatkan moral siswa, kedua pada kegiatan-kegiatan baik kegiatan di dalam lingkungan sekolah atau kegiatan di luar lingkungan sekolah yang berhubungan dengan kegiatan keagamaan guna meningkatkan nilai religius, ketiga penerapan pada keteladanan guru yang bertujuan untuk memberikan contoh moral yang baik bagi siswa sehingga siswa belajar dari model yang sudah ada yaitu guru, keempat pada sarana dan prasarana sekolah, kelima pada tata tertib sekolah yang di susun berdasarkan visi-misi dan tujuan sekolah. Hasil penelitian menunjukkah bahwa strategi tersebut cukup berhasil dalam menguatkan moral siswa. Ada beberapa temuan yang dapat menghambat keberhasilan dari penerapan nilai moral siswa yang ditemukan, seperti: jumlah siswa yang tidak berimbang dengan jumlah kelas, jumlah guru yang kurang ideal, kurang maksimalnya pemanfaatan sarana , kurangnya komitmen warga sekolah terutama kurangnya kerja sama orang tua dalam upaya penguatan moral siswa.

Kata Kunci: Moral, Strategi, Siswa, dan Sekolah Dasar

\section{PENDAHULUAN}

Moral adalah seperangkat keyakinan tentang orang dan tindakan. Moral diartikan sebagai ajaran tentang baik dan buruk yang diterima umum mengenai perbuatan, sikap, akhlak, budi pekerti, dan susila ${ }^{1}$. Orang yang tidak bermoral adalah orang yang tidak berakhlak oleh karena itu pendidikan moral menjadi sebuah solusi untuk mewujudkan manusia yang berbudi, beretika, berakhlak mulia sehingga bisa menjadi pribadi yang lebih bertanggung jawab yang dapat hidup dalam masyarakat dengan baik.

Pengembangan moral bertujuan untuk menjadikan manusia lebih bertanggung jawab dengan apa yang telah dilakukannya. Hal tersebut bisa didapat dalam lingkungan keluarga dan tentunya lingkungan sekolah. Pendidikan moral di sekolah bertujuan agar siswa tidak hanya memiliki kecerdasan intelektual melainkan agar memiliki kecerdasan emosional dan kecerdasan sosial sehingga

1 Ani Nur Aini, Pendidikan Karakter Untuk Mahasiswa PGSD, ed. oleh Julia (Bandung: UPI PRESS, 2014). 
mampu menempatkan dirinya dalam masyarakat dengan menjalankan nilai-nilai dan norma terutama di era modernisasi seperti saat ini.

Sebagaimana kita ketahui bahwa modernisasi telah merambah ke seluruh lini kehidupan manusia. Perkembangan teknologi informasi memberikan kemudahan kepada manusia untuk dapat mengakses informasi apapun dari belahan dunia mana pun. Meskipun demikian terkadang tersebut memberikan dampak negatif terhadap perkembangan moral khususnya siswa. ${ }^{2}$ gradasi moral dikalangan siswa terjadi akibat dari perkembangan teknologi informasi dan komunikasi.

Nilai dan norma tidak dibentuk dengan sengaja seperti hukum tertulis, akan tetapi nilai dan norma berkembang mengikuti kebiasaan manusia. Meskipun kehidupan manusia diatur oleh norma, akan tetapi permasalahan sosial kerap terjadi. Perbedaan kepentingan, kebutuhan, kewenangan, kekuasaan, kemampuan, pola pikir dan kepribadian yang berbeda dari setiap manusia dapat menjadi pemicu terjadinya konflik, kejahatan bahkan kriminalitas, Oleh karena itu pendidikan hadir sebagai salah satu pendekatan yang dianggap sebagai gerakan utama dalam penanaman moral pada siswa, ${ }^{3}$.

Telah banyak penelitian yang pernah di lakukan baik di dalam maupun luar negeri yang berkaitan dengan pendidikan moral siswa sekolah dasar. Seperti penelitian dari ${ }^{4}$ yang menghasilkan pandangan bahwa pendidikan moral siswa dapat memberikan rasa aman dan nyaman disekolah. Selain itu ada juga hasil kajian dari ${ }^{5}$ yang menyebutkan bahwa pendidikan moral bisa menanggulangi dekadensi moral. Lanjut lagi analisis dari ${ }^{6}$ yang menghasilkan kajian bahwa semakin religius seorang siswa moralnya semakin baik. Selain itu masih banyak penelitian terkait moral seperti: ${ }^{7},{ }^{8}, 9$ dimana para peneliti tersebut bersepakat bahwa pendidikan moral mampu membentuk siswa menjadi lebih

2 Y. Wulandari \& Kristiawan, (2017)

3 Rosma Elly dan Nurul Aini, “Agustus 2016 Penanaman Nilai-Nilai Moral Pada Siswa di SD Negeri Kata Kunci : Penanaman, nilai-nilai moral A . Pendahuluan Bangsa Indonesia telah mengalami kemerosotan moral menyangkut persoalan kejujuran, kebenaran, dan keadilan . Sehingga bangsa ini ," 1 (2016), 68-77.

4 Fianolita Purnaningtias et al., (2020)

5 Cahyo, (2017)

6 L. Wulandari, (2019)

7 dwi Bintang Rahmawati Dan I Made Arsana, "Hubungan Pelaksanaan Tata Tertib Sekolah Dengan Pendidikan Moral di SMP Negeri 11 Surabaya Dwi Bintang Rahmawati I Made Arsana Abstrak," 1 (2014).

8 Ludovikus Bomans Wadu dan Yustina Jaisa, "Pembinaan Moral Untuk Memantapkan Watak Kewarganegaraan Siswa Sekolah Dasar Kelas Tinggi," Jurnal Moral Kemasyarakatan, 2.2 (2017), 131 <https://doi.org/10.21067/jmk.v2i2.2256>.

9 Andi Taher, "Pendidikan Moral dan Karakter: Sebuah Panduan Judul: A . Pendahuluan penting terkait dengan pendidikan moral dan karakter. Dukungan nyata terhadap pendidikan moral dan karakter ini terselimuti oleh kontroversi yang cukup besar tentang tindakan yang tep," 14 (2008), 545-58. 
bertanggungjawab dan berkarakter baik. Akan tetapi dari sekian artikel yang ditemukan masih minim kajian-kajian yang mengungkap tentang pengaruh atau dampak dari program sekolah terhadap peningkatan moral siswa sekolah dasar.

Penelitian ini bertuan untuk mengkaji tentang bagaimana usaha sekolah dalam upaya meningkatkan moral siswa, Ini penting mengingat kejahatan dan kriminalitas akibat dari dekadensi moral terus bertambah. Data dari KPAI menyebutkan bahwa kasus anak berhadapan dengan hukum (ABH) pada tahun 2018 mengalami peningkatan dibandingkan tahun sebelumnya. Beragam kasus yang terjadi mulai dari kepemilikan pornografi, kasus pendidikan, kriminalitas dan kejahatan anak. Berikut gambaran data kejahatan yang menempatkan anak sebagai pelaku ${ }^{10}$.

\section{Gambar 1}

Data Kejahatan Anak Tahun 2018

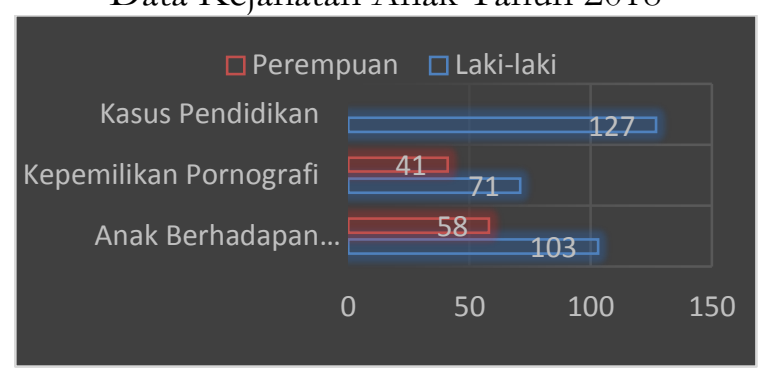

Sumber: KPAI 2018

Data di atas menunjukkan bahwa kasus yang banyak terjadi adalah kasus anak yang berhadapan dengan hukum, artinya adalah anak yang menjadi pelaku kejahatan atau kriminalitas seperti: pencopetan, kekerasan, bahkan pembunuhan dan angka tersebut dilakukan oleh anak-anak dan remaja. Belum lagi banyak kejadian kejahatan dan kriminalitas lainnya. Seperti di kutip dari ${ }^{11}$ yang memberitakan bahwa Sebanyak 122 anak diamankan Polrestro Jakarta Barat. Kasus kekerasan tersebut diantaranya tawuran sebanyak 95 orang, pencurian sebanyak 14 orang, membawa senjata tajam 10 orang, 9 orang kasus begal, 8 orang kasus pengeroyokan, dan kasus penganiayaan lima orang. Hal tersebut menunjukkan bahwa permasalahan moral merupakan masalah yang serius yang perlu segera dicarikan jalan keluar penyelesaiannya.

Seperti yang kita ketahui sekolah merupakan rumah ke dua bagi seorang siswa di mana di sana diajarkan bukan hanya pengetahuan intelektual tetapi untuk

10 KPAI, “KPAI: 4.885 Kasus Pelanggaran Hak Anak, Terbanyak ABH,” KPAI, 2019, hal. 1 <https://www.kpai.go.id/berita/kpai-4-885-kasus-pelanggaran-hak-anak-terbanyak-abh> [diakses 8 Desember 2019].

11 Sindonews.com, "Dalam 1 Tahun, 122 Anak di Jakarta Barat Tersangkut Kriminalitas," Sindo News.Com, $14 \quad$ Maret 2019 $<$ https://metro.sindonews.com/read/1386699/170/dalam-1-tahun-122-anak-di-jakarta-barattersangkut-kriminalitas-1552558428>. 
menciptakan seutuhnya yang bermoral dan beretika sehingga memiliki karakter yang baik. Sekolah menjadi tempat yang strategis kedua setelah keluarga sebagai sarana pengembangan dan penanaman nilai moral seorang manusia. Meskipun tidak ada mata pelajaran khusus terkait dengan moralitas, akan tetapi setiap sekolah pasti mengajarkan moral baik terintegrasi dalam setiap mata pelajaran ataupun dalam budaya sekolah seperti visi-misi sekolah, tata tertib sekolah, ataupun program pengembangan diri sehingga sekolah memiliki desain untuk menjadikan siswa lebih berkarakter dan lebih bermoral. Berkaitan dengan itu maka kami berupaya untuk mengungkap tentang "bagaimana strategi penguatan moral siswa di SDN 4 Cakranegara Mataram".

Untuk mengkaji permasalahan di atas kami menggunakan metode deskriptif dengan teknik wawancara dan observasi. Wawancara dilakukan kepada kepala sekolah dan dan 2 orang guru serta 1 tenaga kependidikan. Selain itu observasi dilakukan dalam kurun waktu penelitian yaitu selama semester genap tahun pelajaran 2019-2020. Setelah data diperoleh selanjutnya di analisis melalui tahapan pengumpulan data, penyajian data dan penarikan kesimpulan ${ }^{12}$.

\section{Hasil dan Pembahasan}

Seperti sekolah pada umumnya, SDN 4 Cakranegara Mataram merupakan sebuah sekolah negeri yang cukup terkemuka. lokasi yang berada di kawasan padat penduduk menyebabkan latar belakang siswa yang beragam sehingga memiliki karakteristik yang berbeda pula. Pada dasarnya keberagaman akan berpengaruh dalam penerapan dan penguatan moral siswa akan tetapi keberhasilan penguatan moral siswa tergantung dari sejauh mana strategi sekolah dalam membiasakan, membimbing, dan mengarahkan siswa untuk memiliki moral yang baik.

Seperti yang dikatakan oleh kepala sekolah bahwa "keberhasilan sebuah program memerlukan sinergitas dari berbagai pihak. Dalam hal ini harus ada kerja sama antara sekolah, orang tua, dan lingkungan sekitar. Begitu pula dalam penguatan moral, tentunya harus benar-benar dipersiapkan dan dalam penerapannya harus melibatkan semua pihak terutama keluarga". Berdasarkan hasil observasi dan wawancara, strategi yang dilakukan oleh sekolah SDN 4 Cakranegara Mataram untuk menguatkan moral siswa yaitu melalui Visi-misi sekolah, kegiatan-kegiatan sekolah, keteladanan guru, sarana dan prasarana. Secara lengkap dideskripsikan di bawah ini

Visi misi di susun dengan melibatkan seluruh komponen yang terkait dengan sekolah baik itu guru, kepala sekolah, dan komite sekolah. Di SDN 4 Cakranegara Mataram sendiri visi misi menjadi landasan dalam menjalankan program sekolah, disusun berdasarkan kepentingan siswa yang menyiratkan

12 Sugiono, Metode Penelitian Pendidikan (Pendekatan Kuantitatif, Kualitatif, dan R\&D). (Bandung: Alfabeta, 2013). 
tentang perbaikan kualitas hidup siswa terutama dalam penguatan karakter dan moral. Berikut gambar visi misi dan tujuan sekolah SDN 4 Cakranegara

\section{Gambar 2}

Visi-Misi Dan Tujuan Sekolah

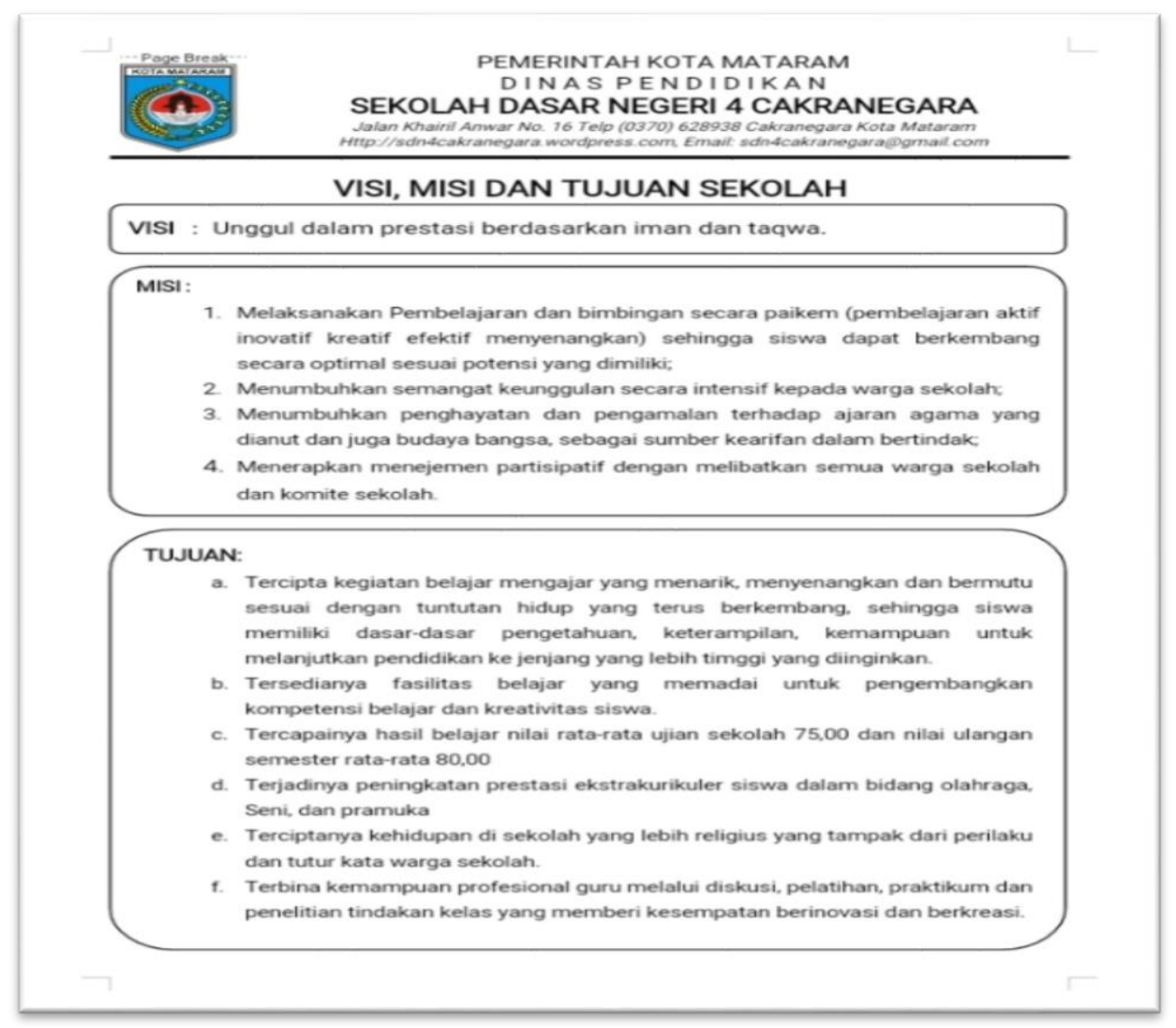

\section{Sumber: Dokumen SDN 4 Cakranegara}

Ada beberapa poin penting dalam visi-misi dan tujuan sekolah yang mengarah kepada penguatan moral siswa di antaranya iman, takwa, dan religius. Hal tersebut menunjukkan keseriusan sekolah dalam menguatkan nilai moral siswa. Hasil wawancara dengan kepala sekolah menegaskan bahwa visi-misi dirancang sedemikian rupa guna mempersiapkan siswa-siswi yang siap bersaing dimasa yang akan datang dengan dilandasi dengan moral dan nilai keagamaan yang kuat. Selain visi misi, sekolah pula memajang poster yang berisikan slogan-slogan positif guna menstimulus warga sekolah agar memiliki moral dan karakter yang lebih baik. Seperti gambar di bawah ini: 


\section{Gambar 3}

Poster

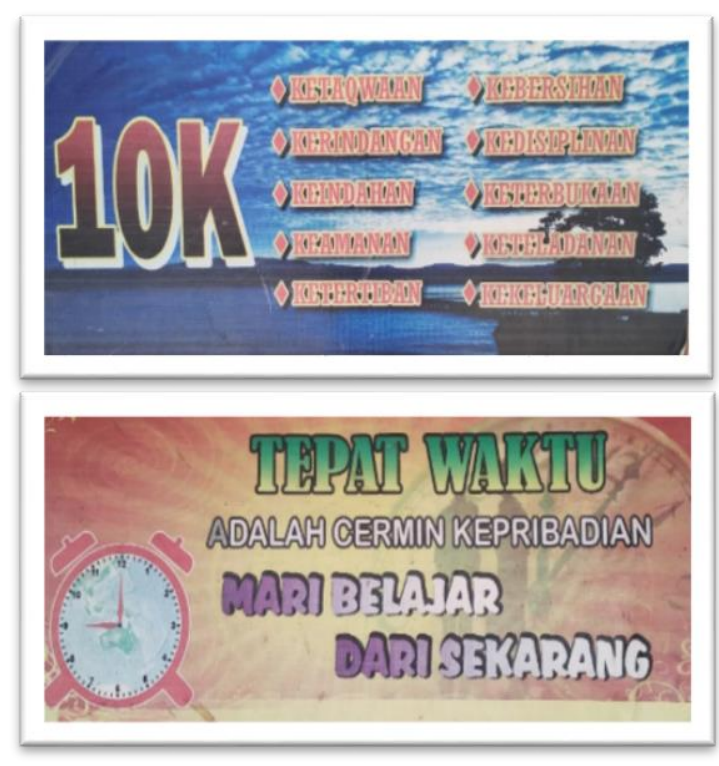

Sumber: Dokumen sekolah

Makna yang terkandung dalam setiap kata pada poster di atas mengandung arti begitu mendalam. Bukan hanya sebuah-kata-kata, melainkan sebuah energi yang diharapkan dapat menarik warga sekolah untuk melaksanakan arti dari setiap kata tersebut. Hasil wawancara menjelaskan bahwa tujuan dari di buat poster seperti itu agar setiap warga sekolah dapat melihat setiap waktu dan diharapkan dapat tertanam dalam pikiran dan dapat merealisasikan dalam lingkungan sekolah dan dalam masyarakat. beliau sedikit menjelaskan tentang beberapa poin dari poster tersebut terutama pada poster yang bertema $10 \mathrm{~K}$, di mana memuat kata ketakwaan, keteladanan, kekeluargaan, kedisiplinan, ketertiban, keamanan, dan kaitannya dengan penguatan moral siswa.

Ketakwaan Artinya sejauh mana seorang siswa dapat mengenal tuhannya sehingga dapat meningkatkan nilai keagamaan. Kita tahu bahwa di saat seseorang kuat agamanya maka sikap, perilaku akan tercermin dalam akhlaknya sehingga moral yang baik akan menjadi bagian tak terpisahkan dalam hidupnya. Keteladanan Dalam hal ini warga sekolah diharapkan bisa menjadi teladan untuk yang lainnya. Misalkan kepala sekolah menjadi teladan untuk guru-gurunya, dan guru menjadi teladan bagi siswanya. Dengan demikian guru atau kepala sekolah akan mudah untuk mengarahkan siswa menjadi lebih baik. Pendidikan terbaik adalah pendidikan di mana seorang guru bisa menjadi contoh untuk siswanya. 
Kekeluargaan merupakan rasa aman dan nyaman seorang manusia akan dirasakan di saat mereka berada pada lingkungan keluarga. Hal tersebut yang coba kami lakukan disekolah agar siswa merasa sekolah menjadi rumah kedua dan menjadi tempat untuk mengembangkan diri potensi (Kutipan bapak kepala sekolah pada saat wawancara). Bukan hanya antara guru dan murid, akan tetapi untuk semua warga sekolah agar dapat menciptakan lingkungan yang penuh dengan rasa kekeluargaan sehingga dapat menciptakan sekolah yang aman, nyaman dan tertib. Ketertiban. Ditujukan bukan hanya untuk siswa, tetapi untuk semua warga sekolah guna menciptakan keseimbangan dalam pendidikan dan pengajaran. Tertib artinya aman, damai, terkendali dan mengikuti semua aturan sekolah. Sekolah sangat memperhatikan hal ini agar tidak menciptakan celah untuk siswa berbuat yang menyalahi aturan sehingga mengarah kepada moral yang tidak seharusnya.

Temuan-temuan di atas menunjukkan bahwa pada dasarnya strategi sekolah dalam upaya penguatan moral siswa sudah tepat. Pertama dalam hal visi misi sekolah SDN 4 Cakra negara telah memiliki visi-misi yang disusun berdasarkan ketentuan dan melibatkan berbagai kalangan dalam merumuskan demi kepentingan dan cita-cita sekolah dimasa yang akan datang Visi adalah imajinasi moral yang menggambarkan profil sekolah yang di inginkan di masa datang, dan Misi merupakan tindakan atau upaya untuk mewujudkan visi ${ }^{13}$ jadi visi misi sekolah merupakan sebuah acuan atau patokan atau cita-cita atau harapan yang menjadi tujuan sekolah dimasa yang akan datang.

Beberapa indikator yang terkandung dalam visi dan misi SDN 4 Cakranegara adalah, kejujuran, kedisiplinan, beriman, bertakwa, religius, hormat pada orang tua dan guru, dan yang lainnya. Hal tersebut merupakan sebuah cerminan manusia yang berkarakter baik sehingga siswa yang memiliki karakter yang baik akan memiliki moral yang baik pula. Selain itu penerapan moral siswa di SDN 4 Cakra negara terintegrasi ke dalam aspek di bawah ini, seperti:

Pertama Kegiatan Sekolah. Kegiatan sekolah terfokus pada kegiatan di dalam sekolah, kegiatan di luar sekolah, dan kegiatan ekstra kurikuler. Dari hasil observasi dan wawancara, penguatan moral pada siswa di lakukan melalui penguatan nilai religius atau keagamaan, seperti: pembiasaan-pembiasaan dari mengucap salam pada saat datang, membaca doa sebelum dan sesudah selesai pembelajaran, Shalat berjamaah, dan kegiatan keagamaan yang di lakukan setiap hari Jumat. Doa bersama sebelum pembelajaran bisa di katakana wajib, meskipun tidak tertulis pada tata tertib sekolah. Selain itu, di SDN 4 Cakranegara juga rutin melaksanakan upacara besar keagamaan, seperti memperingati hari Maulid Nabi atau Isra Mi'raj dan yang lainnya. Selain kegiatan di dalam sekolah, ada juga kegiatan di luar sekolah dalam upaya meningkatkan nilai-nilai religius guna menguatkan nilai moral siswa seperti, lomba-lomba bernuansa keislaman seperti

13 Amnah Qurniati Ahmad Calam, "Merumuskan Visi dan Misi Lembaga Pendidikan, Jurnal Ilmiah SAINTIKOM Sain dan Komputer," Jurnal Ilmiah Saintik, 15.1 (2016), 53-68 <https://prpm.trigunadharma.ac.id/public/fileJurnal/hp1k6 MakalahFuturologi.pdf>. 
MTQ. Hal tersebut dilakukan semata-mata untuk menguatkan karakter religius siswa sehingga siswa memiliki moral yang baik. Berikut beberapa gambar pembiasaan siswa yang mencerminkan penanaman nilai-nilai religius :

\section{Gambar 4 Doa Bersama}

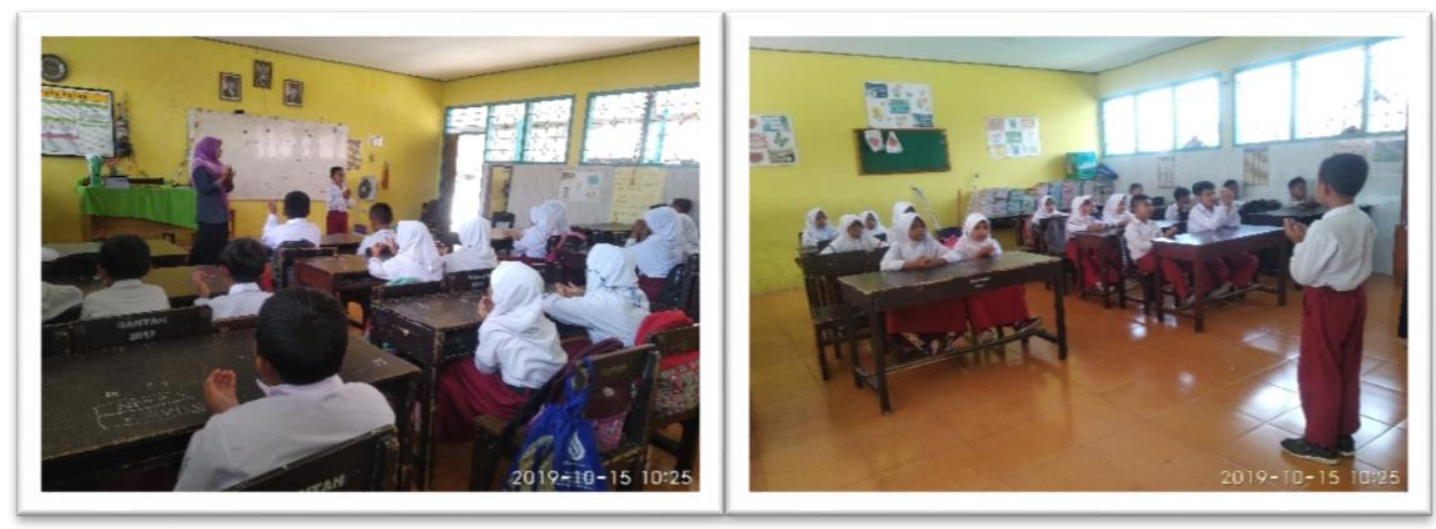

Sumber: Dokumen Penelitian

Penanaman nilai keagamaan merupakan salah satu upaya untuk menguatkan moral kepada anak. Agama mengajarkan keyakinan, kebenaran yang hakiki sehingga dapat menciptakan suatu pola harmonis dalam hubungan antar manusia. Ritual keagamaan yang dilakukan secara fisik harus dirasakan secara psikis dan di aplikasikan dalam perbuatan yang bernilai moral ${ }^{14}$, artinya pembisaan pembiasaan kegiatan keagamaan guna membentuk suatu watak manusia yang secara tidak langsung akan membentuk suatu kepribadian yang baik yang tercermin dalam tingkah laku.

Kedua Keteladanan Guru. Pada dasarnya sebagian besar guru di SDN 4 Cakranegara telah menunjukkan teladan yang baik untuk para siswanya. Hal tersebut terlihat dari sikap, cara bertutur kata, cara memperlakukan siswa, dan cara bertingkah laku disekolah. Hal tersebut sesuai dengan amanat PERMENDIKNAS NO 16 Tahun 2007 tentang standar akademik dan kompetensi guru di mana guru harus memiliki kompetensi pedagogi, kepribadian, sosial dan profesional. Keteladanan guru erat kaitannya dengan keempat kompetensi tersebut terutama kompetensi kepribadian yang menekankan bahwa guru harus Bertindak sesuai dengan norma agama, hukum, sosial, dan kebudayaan nasional Indonesia, Menampilkan diri sebagai pribadi yang jujur, berakhlak mulia, dan teladan bagi peserta didik dan masyarakat, Menampilkan diri sebagai pribadi yang mantap, stabil, dewasa, arif, dan berwibawa, Menunjukkan etos kerja, tanggung jawab yang tinggi, rasa bangga menjadi guru, dan rasa percaya diri, Menjunjung tinggi kode etik profesi guru.

14 Iredho Fani reza, "Hubungan antara Religiusitas dengan Moralitas pada Remaja di Madrasah Aliyah (MA)," $2013, \quad 45-58$ <https://www.academia.edu/8340999/Religiusitas_dan_Moralitas>. 
Seperti yang telah dibahas di atas, Guru merupakan syarat terdepan dalam penyelenggaraan pendidikan. Guru bukan hanya sebagai pengajar, melainkan sebagai pendidik, pentransfer, pembimbing, penentu arah tujuan, dan sebagai panutan. Guru juga bukan hanya sebagai profesi tetapi guru harus bisa menjadi seorang ayah, menjadi ibu, bahkan menjadi sahabat untuk para siswanya. Hal tersebut dimaksudkan guna memudahkan seorang guru dalam mencapai tujuan pembelajaran. Kaitannya dalam penguatan moral siswa guru hendaklah menjadi teladan yang baik karena cara yang baik dalam mengajar adalah guru sendiri yang menjadi contoh ${ }^{15}$. Seperti yang dikatakan oleh kepala sekolah bahwa "setiap guru di wajibkan untuk menjadi panutan. Bukan hanya tataran teori akan tetapi guru melihat apa yang dilakukan oleh gurunya sehingga secara langsung ataupun tidak langsung siswa akan meniru".

Dalam usaha penguatan moral guru dituntut menjadi teladan karena jika di telaah istilah Bahasa arab guru dapat diartikan sebagai mu'addib (etika, moral dan adab) yang berarti orang beradab yang memiliki peran dan fungsi membangun suatu peradaban yang berkualitas di era mendatang, orang yang mampu memberikan pendidikan kepada peserta didik, agar mampu berkreasi, mengatur, dan memelihara hasil kreasinya untuk kemaslahatan umum dan tidak menimbulkan malapetaka bagi diri, masyarakat dan alam. Mursyid, yaitu orang yang mengajarkan dan menularkan penghayatan akhlak dan kepribadian kepada peserta didik, ${ }^{16}$. Hal tersebut menegaskan bahwa guru bukan hanya sekedar menjadikan siswa bodoh menjadi pintar, bukan hanya menjadikan siswa yang tidak tahu menjadi tahu, tapi sejauh mana guru bisa menjadi sorang panutan yang mampu memberikan pengajaran dan pendidikan dari kepribadian akhlak dirinya sehingga guru dapat menjadi jembatan dalam penguatan moral siswa.

Dalam mengimplementasikan program pendidikan guru memiliki peran penting dan menjadi anak panah penentu keberhasilan program sekolah ${ }^{17}$. Penguatan moral yang dilakukan oleh guru bukan hanya sekedar mengajarkan teori, tetapi bagaimana caranya guru menjadi model dan contoh. Implikasi yang paling dekat adalah semua Guru, tidak pandang mata pelajaran yang diajarkannya memiliki tanggung jawab membangun moral dan karakter anak didik ${ }^{18}$. Siswa akan mudah belajar dari apa yang mereka lihat, terutama bersumber dari orang

15 Deni Sutisna, Dyah Indraswati, dan Muhammad Sobri, "Keteladanan Guru sebagai

Sarana Penerapan Pendidikan Karakter Siswa,” JPDI (Jurnal Pendidikan Dasar Indonesia), 2019

$<$ https://doi.org/10.26737/jpdi.v4i2.1236>.

16 ( Rama yulis dalam Ahyan Yusuf Sya'bani, 2018)

17 Dyah Indraswati et al., "critical thinking dan problem solving dalam pembelajaran ips untuk menjawab tantangan abad 21," Sosial Horizon, Jurnal Pendidikan Sosial, 7.1 (2020), 12-28 $<$ https://journal.ikippgriptk.ac.id/index.php/sosial/article/view/1540>.

18 Leonie Francisca dan Clara R.P Ajisukmo, "The correlations among moral knowing, moral feeling, and moral behavior on four basic competencies of teachers," Jurnal Kependidikan. Penelitian Inovasi Pembelajaran, 45.2 (2015), <https://doi.org/KETERKAITAN ANTARAMORAL KNOWING, MORAL FEELING, DAN BEHAVIOR PADA EMPAT KOMPETENSI DASAR GURU Leonie>. 
terdekat atau orang yang mereka segani. Menghargai siswa, menghormati siswa, memperlakukan siswa dengan ramah, tidak menyudutkan siswa, memberi semangat siswa menunjukkan rasa hormat dan tanggung jawab merupakan cerminan dari penanaman moral yang otomatis akan dilihat oleh siswa dan secara langsung atau tidak langsung, cepat atau lambat siswa akan menirunya.

Sebagai Manager di dalam kelas, guru harus memiliki pemahaman terkait dengan nilai-nilai pendidikan ${ }^{19}$. Ada beberapa ide besar dalam nilai-nilai pendidikan yang ditujukan dalam rasa hormat dan tanggung jawab mengajar; 1). Sepanjang sejarah, pendidikan memiliki dua tujuan utama, yaitu membantu orang menjadi pintar dan lebih baik; 2). Baik diartikan sebagai moral yang memiliki kebaikan yang objektif, yaitu nilai-nilai yang memperkuat martabat manusia dan memajukan kebaikan individu dan masyarakat; 3). Terdapat dua nilai universal moral yang dapat membuat inti masyarakat yaitu rasa respek dan tanggung jawab adapun hal pula tersebut dapat diajarkan; 4). Respek adalah menunjukkan rasa hormat kepada seseorang atau sesuatu yang berharga. Termasuk pada diri sendiri, yaitu respek terhadap harkat dan martabat manusia, dan respek pada lingkungan yang menyokong kehidupan. Respek menopang semua sisi moral ${ }^{20}$.

Dengan desain pendidikan karakter berbasis kecerdasan moral yang diaktualisasikan secara sistematis dan berkelanjutan, peserta didik akan memiliki sejumlah kebajikan utama yang berguna bagi dirinya dalam menghadapi segala macam tantangan kehidupan, termasuk tantangan untuk berhasil secara akademis ${ }^{21}$. Ada beberapa aspek yang dapat menjadi indikator penguatan moral siswa, di antaranya: lingkungan sekolah yang baik dan dapat menjadi sarana, kurikulum yang digunakan, melalui kegiatan-kegiatan sekolah baik kegiatan di dalam dan di luar sekolah, tenaga pendidik dan kependidikan yang mampu memfasilitasi siswa dalam penguatan moral, bekerja sama dengan berbagai elemen masyarakat seperti orang tua dan komite sekolah ${ }^{22}$

Ketiga melalui Sarana Dan Prasarana Sekolah. Untuk menciptakan ketertiban, keamanan, kenyamanan sarana dan prasarana sekolah harus mendapatkan perhatian, lokasi SDN 4 cakra negara yang berada di pinggir jalan menjadikan lokasi sekolah yang perlu memperhatikan keamanan siswa terutama pada saat masuk dan pulang sekolah. Hasil observasi menunjukkan sekolah sudah menata sedemikian rupa demi menciptakan keamanan dan kenyamanan

19 Dyah Indraswati dan Deni Sutisna, "Implementasi Manajemen Mutu di SDN Prambon,” Jurnal Dinamika Manajemen Pendidikan (JDMP), 5.1 (2020), 10-21.

20 Thomas Lichona, Educating For Character How Our Shool can teach, respect, and responsibility (Jakarta: PT Bumi Aksara, 2015).

21 Deny Setiawan, "Peran Pendidikan Karakter dalam Mengembangkan Kecerdasan Moral," Jurnal Pendidikan Karakter, 1 (2013), 58 <https://doi.org/ MORAL https://doi.org/10.21831/jpk.v0i1.1287>.

22 A Safril Mubah, "Revitalisasi Identitas Kultural Indonesia di Tengah Upaya Homogenisasi Global," Jurnal Global dan strategis, Vol 5.No 3 (2011), 251-60 <https://doi.org/10.1108/20466091211287128>. 
penyelenggaraan pendidikan. Bisa terlihat dari gedung sekolah yang masih kokoh berdiri, dan cukup rapi, gerbang yang ideal, dan kantin yang berada di dalam lingkungan sekolah. Selain itu, seluruh ruangan yang berada di sana cukup representatif untuk penyelenggaraan pembelajaran. Hal tersebut terlihat dari kelengkapan ruangan berupa meja kursi belajar, meja dan kursi guru, lemari guru, meja hasil kerja siswa, pencahayaan alami, dan sirkulasi udara yang alami pula. Kutipan wawancara dengan kepala sekolah menyebutkan bahwa demi tercapainya pendidikan yang berkualitas kita harus memperhatikan berbagai aspek, bukan hanya guru dan warga sekolah yang harus dipersiapkan, tetapi sarana dan prasarana juga perlu diperbaiki. Hal tersebut menjadi suatu penunjang karena program sekolah memerlukan dukungan sarana prasarana serta culture sekolah yang baik sehingga program sekolah pun berjalan dengan maksimal ${ }^{23}$.

Keempat melalui tata tertib sekolah. Tata tertib pada dasarnya merupakan turunan dari visi-misi dan tujuan sekolah. Tata tertib disusun berdasarkan tujuan untuk membentuk budaya sekolah yang sesuai dengan visi-misi dan tujuan sekolah di mana di sana menekankan tentang hak dan kewajiban siswa selama menjadi warga sekolah. Isi dari tata tertib, SDN 4 Cakranegara menyiratkan tentang bagaimana membentuk siswa menjadi lebih bertanggung jawab, beretika, beriman, bertakwa dan bermoral. Budaya sekolah yang tercermin dalam tata tertib sekolah sudah menunjukkan keseriusan dalam membentuk siswa untuk menjadi lebih unggul, berkualitas. Mari kita coba analisis beberapa hal yang ada pada tata tertib SDN 4 Cakranegara.

Pertama pada poin hal masuk sekolah. Di sana dijelaskan bahwa siswa harus masuk 5 menit sebelum pelajaran dimulai, murid yang terlambat harus melapor ke guru piket, harus ada surat keterangan jika tidak masuk sekolah semisal sakit atau yang lainnya, tidak diperkenankan keluar kelas selama pelajaran berlangsung kecuali ada keperluan yang sangat penting dan mendadak. Hal tersebut dimaksudkan untuk membentuk siswa menjadi pribadi yang lebih disiplin dan bertanggungjawab karena tanggung jawab merupakan cerminan seseorang dalam pertanggung jawaban sosial baik bagi dirinya masyarakat dan lingkungan baik fisik maupun sosial sehingga seseorang menjadi pribadi yang siap hidup bermasyarakat ${ }^{24}$. Hal tersebut merupakan kebutuhan yang mutlak diperlukan oleh seseorang untuk menjadi bekal hidup di masyarakat, oleh karena itu SDN 4 Cakra negara selalu terus berupaya menerapkan tanggung jawab baik itu siswa, guru dan seluruh warga sekolah.Kedua, pada poin kewajiban murid/siswa, di mana siswa diwajibkan untuk taat kepada guru dan kepala sekolah, bertanggungjawab dalam kebersihan dan perawatan lingkungan sekolah dan gedung sekolah, menjaga nama

23 Deni Sutisna et al., "Penerapan Program Pendidikan Inklusi Di SDN 1 Sangkawana Lombok Tengah,” Progres Pendidikan, 1.2 (2020), 115-27 $<$ http://prospek.unram.ac.id/index.php/PROSPEK/index\%0APENERAPAN>.

24 Ratri Rahayu, "Peningkatan Karakter Tanggung Jawab Siswa Sd Melalui Penilaian

Produk Pada Pembelajaran Mind Mapping," Jurnal Konseling Gusjigang, 2.1 (2016) $<$ https://doi.org/10.24176/jkg.v2i1.562>. 
baik sekolah, hormat kepada guru dan kepala sekolah, dan wajib menjalankan tata tertib sekolah. Hal tersebut menunjukkan bahwa siswa diarahkan agar memiliki karakter yang memiliki moral yang baik. Moral seseorang akan terlihat dari bagaimana cara dia berinteraksi, bersosialisasi dan berkomunikasi dengan yang lainnya. Di saat seseorang Saling menghormati, saling menghargai, saling mencintai maka akan tercermin kepribadiannya dan akan terlihat nilai moral yang dimilikinya ${ }^{25}$.Ketiga, pada hal larangan murid dan aturan berpakaian. Ada beberapa poin dalam ini yang berkaitan dengan penguatan moral siswa, seperti larangan merokok, berdandan, memakai perhiasan yang berlebihan, menyontek, berkelahi, dan menggunakan seragam sesuai dengan kaidah. Hal tersebut dalam rangka mengendalikan moral siswa melalui pembiasaan-pembiasaan.

Pembiasaan merupakan cikal-bakal dari pembentukan moral, Pendidikan moral bertujuan untuk mempromosikan perkembangan pembentukan karakter siswa ${ }^{26}$. Dengan demikian program SDN 4 Cakra negara sebetulnya telah mengarah kepada pembentukan karakter siswa. Akan tetapi dalam penerapannya masih mengalami kendala. Ada beberapa temuan yang menjadi kendala dalam penguatan moral siswa di SDN 4 Cakranegara, pertama adalah kurangnya fasilitas ruang belajar siswa sehingga mereka mengalami sedikit kesulitan dalam mengelola siswa dalam artian masih ada siswa yang masuk siang karena kelasnya di pakai dulu oleh kelas lain selain kurang pemanfaatan fasilitas juga sebetulnya masih bisa di maksimalkan dalam upaya penguatan moral siswa. Contohnya gerbang sekolah yang tidak di kunci bahkan cenderung terbuka. Hal tersebut bisa memberikan kesempatan kepada siswa untuk keluar lingkungan sekolah Kedua, kurangnya tenaga pengajar, sehingga beberapa di antara guru di sana ada yang mengajar kelas gemuk dengan jumlah siswa melebihi jumlah ideal. Hal tersebut berdampak pada kurangnya kenyamanan belajar dan kurangnya perhatian guru disebabkan siswa yang terlalu banyak. Kaitannya dengan penguatan moral ini berhubungan dengan bagaimana kemampuan guru dalam mengelola kelas. Semakin kelas gemuk maka semakin besar tantangan guru dalam mengelola kelas. Ketiga, belum optimalnya antara program sekolah dengan implementasi yang di lakukan di lapangan dan kurangnya respon yang positif dari orang tua siswa.

Dalam usaha menguatkan moral siswa, sekolah tidak akan optimal jika tidak bekerja sama dengan orang tua atau wali. Tidak sedikit orang tua yang acuh tak acuh terhadap moral anaknya. Disekolah diarahkan untuk memiliki moral yang baik, sementara di lingkungan keluarga di biarkan saja sehingga tidak terjadi keseimbangan antara pendidikan disekolah dan di keluarga. Keempat kurangnya kesadaran orang tua dalam hal mendidik anak. Hal ini merupakan kasus yang sering terjadi bukan hanya di SDN 4 Cakra negara saja, akan tetapi di sekolah-

25 Siti Nurhalimah, Media Sosial dan Masyarakat Pesisir (Yogyakarta: CV Budi Utama, 2019).

26 Mohammad Chowdhury, "Emphaysizing Morals, Values, Ethics, and Character Education in Science Education and Science Teaching.," Malaysian Online Journal of Educational Sciences, 4.2 (2016), 1-16. 
sekolah lain pun pasti kerap terjadi. Banyak kejadian anaknya yang di arahkan disekolah tetapi orang tuanya malah tersinggung alhasil sekolah terkendala dan segan untuk mendidik siswa yang seperti itu, belum lagi jika orang tuanya seseorang yang sedikit berpengaruh atau dan selalu menuruti kehendak anaknya dan tidak percaya dengan pola pendidikan disekolah, maka cenderung siswa dari latar belakang keluarga seperti itu tergolong siswa yang nakal, tidak memiliki sopan santung bahkan bisa jadi pembangkang.

\section{KESIMPULAN}

Secara singkat penelitian ini dapat ditarik kesimpulan bahwa strategi penguatan moral siswa di SDN 4 Cakranegara sudah tepat sasaran meskipun dalam penerapannya masih ditemukan beberapa kelemahan-kelemahan yang sebetulnya masih dapat dimaksimalkan. Ada beberapa lini yang sentuh dalam upaya penguatan moral siswa di antaranya pada perencanaan sekolah yang disusun dalam visi-misi dan tujuan sekolah yang di dalamnya sudah memperhatikan konten yang erat kaitannya dengan upaya penguatan moral siswa seperti beriman, bertakwa, jujur, disiplin, hormat dan religius, pada kegiatan-kegiatan sekolah baik kegiatan di dalam dan di luar lingkungan sekolah terutama kegiatan yang mengangkat nilai-nilai keagamaan, pada keteladanan guru yang diharapkan bisa menjadi contoh untuk siswanya, dan pada sarana-prasarana lingkungan sekolah guna memfasilitasi tumbuh kembang dan kegiatan pembelajaran siswa.

Sebagai masukan kepada penelitian berikutnya bahwasanya moral merupakan modal utama bagi kehidupan bermasyarakat. Masa pandemi seperti saat ini memaksa kita harus beradaptasi dengan menjalankan segala sesuatu dari rumah, begitu juga dengan pembelajaran. Oleh karena itu kajian atau penelitian terkait peran sekolah dalam penanaman pendidikan moral siswa sangat diperlukan.

\section{DAFTAR PUSTAKA}

Ahmad Calam, Amnah Qurniati, "Merumuskan Visi dan Misi Lembaga Pendidikan, Jurnal Ilmiah SAINTIKOM Sain dan Komputer," Jurnal Ilmiah Saintik, $\quad 15.1 \quad$ (2016), 53-68 $<$ https://prpm.trigunadharma.ac.id/public/fileJurnal/hp1k6 MakalahFuturologi.pdf $>$

Ahyan Yusuf Sya'bani, Mohammad, Profesi Keguruan (menjadi guru yang religius dan bermartabat) (Gresik: Caremidea Communication, 2018) $<$ http://eprints.umg.ac.id/id/eprint/82>

Cahyo, Edo Dwi, "Pendidikan Karakter Guna Menanggulangi Dekadensi Moral Yang Terjadi Pada Siswa Sekolah Dasar," EduHumaniora | Jurnal Pendidikan $\begin{array}{llll}\text { Dasar Kampus } \quad \text { Cibiru, } & 9.1 \quad 16\end{array}$ $<$ https://doi.org/10.17509/eh.v9i1.6150>

Chowdhury, Mohammad, "Emphaysizing Morals, Values, Ethics, and Character 
Education in Science Education and Science Teaching.," Malaysian Online Journal of Educational Sciences, 4.2 (2016), 1-16

Elly, Rosma, dan Nurul Aini, "Agustus 2016 PENANAMAN NILAI-NILAI

MORAL PADA SISWA DI SD NEGERI Kata Kunci : Penanaman, nilainilai moral A . PENDAHULUAN Bangsa Indonesia telah mengalami kemerosotan moral menyangkut persoalan kejujuran, kebenaran, dan keadilan . Sehingga bangsa ini ," 1 (2016), 68-77

Fani reza, Iredho, "Hubungan antara religiusitas dengan moralitas pada remaja di madrasah aliyah (ma)," 2013, 45-58 <https://www.academia.edu/8340999/Religiusitas_dan_Moralitas>

Fianolita Purnaningtias, Nuril Aika, Lisanatul Fasihah, Moh Salman Al Farisi, Ahmad Sucipto, dan Zherin Mei Biana Putri, "ANALISIS PERAN PENDIDIKAN MORAL UNTUK MENGURANGI AKSI BULLY DI SEKOLAH DASAR," 4.1 (2020)

Francisca, Leonie, dan Clara R.P Ajisukmo, "The correlations among moral knowing, moral feeling, and moral behavior on four basic competencies of teachers," Jurnal Kependidikan. Penelitian Inovasi Pembelajaran, 45.2 (2015), 211$21<$ https://doi.org/KETERKAITAN ANTARAMORAL KNOWING, MORAL FEELING, DAN MORAL BEHAVIOR PADA EMPAT KOMPETENSI DASAR GURU Leonie>

Indraswati, Dyah, Dina Anika Marhayani, Deni Sutisna, Arif Widodo, dan Mohammad Archi Mauilida, "critical thinking dan problem solving dalam pembelajaran ips untuk menjawab tantangan abad 21," Sosial Horizon, Jurnal $\begin{array}{llll}\text { Pendidikan } & \text { Sosial, } & 7.1 & \text { (2020), }\end{array}$ $<$ https://journal.ikippgriptk.ac.id/index.php/sosial/article/view/1540>

Indraswati, Dyah, dan Deni Sutisna, "Implementasi Manajemen Mutu di SDN Prambon," Jurnal Dinamika Manajemen Pendidikan (JDMP), 5.1 (2020), 10-21 KPAI, "KPAI: 4.885 Kasus Pelanggaran Hak Anak, Terbanyak ABH," KPAI, 2019, hal. 1 <https://www.kpai.go.id/berita/kpai-4-885-kasuspelanggaran-hak-anak-terbanyak-abh $>$ [diakses 8 Desember 2019]

Mubah, A Safril, "Revitalisasi Identitas Kultural Indonesia di Tengah Upaya Homogenisasi Global," Jurnal Global dan strategis, Vol 5.No 3 (2011), 251-60 <https://doi.org/10.1108/20466091211287128>

Nur Aini, Ani, Pendidikan Karakter Untuk Mahasiswa PGSD, ed. oleh Julia (Bandung: UPI PRESS, 2014)

Nurhalimah, Siti, Media Sosial dan Masyarakat Pesisir (Yogyakarta: CV Budi Utama, 2019)

Rahayu, Ratri, "Peningkatan Karakter Tanggung Jawab Siswa Sd Melalui Penilaian Produk Pada Pembelajaran Mind Mapping," Jumal Konseling Gusjigang, 2.1 (2016) < https://doi.org/10.24176/jkg.v2i1.562>

Rahmawati, Dwi Bintang, dan I Made Arsana, "HUBUNGAN PELAKSANAAN TATA TERTIB SEKOLAH DENGAN PENDIDIKAN MORAL DI SMP NEGERI 11 SURABAYA Dwi Bintang 
Rahmawati I Made Arsana Abstrak," 1 (2014)

Setiawan, Deny, "Peran Pendidikan Karakter dalam Mengembangkan Kecerdasan

Moral," Jumal Pendidikan Karakter, 1 (2013), 58

<https://doi.org/https://doi.org/10.21831/jpk.v0i1.1287>

Sindonews.com, "Dalam 1 Tahun, 122 Anak di Jakarta Barat Tersangkut

Kriminalitas," Sindo News.Com, 14 Maret 2019

$<$ https://metro.sindonews.com/read/1386699/170/dalam-1-tahun-122-

anak-di-jakarta-barat-tersangkut-kriminalitas-1552558428>

Sugiono, Metode Penelitian Pendidikan (Pendekatan Kuantitatif, Kualitatif, dan RひD).

(Bandung: Alfabeta, 2013)

Sutisna, Deni, Dyah Indraswati, Nursaptini, Setiani Novitasari, dan Muhammad

Sobri, "Penerapan Program Pendidikan Inklusi Di SDN 1 Sangkawana

Lombok Tengah," Progres Pendidikan, 1.2 (2020), 115-27

$<$ http://prospek.unram.ac.id/index.php/PROSPEK/index\%0APENERA PAN $>$

Sutisna, Deni, Dyah Indraswati, dan Muhammad Sobri, "Keteladanan Guru sebagai Sarana Penerapan Pendidikan Karakter Siswa," JPDI Jurnal Pendidikan Dasar Indonesia), 2019 $<$ https://doi.org/10.26737/jpdi.v4i2.1236>

Taher, Andi, "PENDIDIKAN MORAL DAN KARAKTER: SEBUAH PANDUAN Judul: A . Pendahuluan penting terkait dengan pendidikan moral dan karakter. Dukungan nyata terhadap pendidikan moral dan karakter ini terselimuti oleh kontroversi yang cukup besar tentang tindakan yang tep," 14 (2008).

Thomas Lichona, Educating For Character How Our Shool can teach, respect, and responsibility (Jakarta: PT Bumi Aksara, 2015)

Wadu, Ludovikus Bomans, dan Yustina Jaisa, "Pembinaan Moral Untuk Memantapkan Watak Kewarganegaraan Siswa Sekolah Dasar Kelas Tinggi," Jurnal Moral Kemasyarakatan, 2.2 (2017), <https://doi.org/10.21067/jmk.v2i2.2256>

Wulandari, Luluk, "Pengaruh Religiusitas Terhadap Perkembangan Moral Siswa Menengah Atas," Prosiding Seminar Nasional \& Call Paper, 2019,

Wulandari, Yeni, dan Muhammad Kristiawan, "Strategi Sekolah Dalam Penguatan Pendidikan Karakter Bagi Siswa Dengan Memaksimalkan Peran Orang Tua," JMKSP Jurnal Manajemen, Kepemimpinan, dan Supervisi Pendidikan, 2.2

(2017),

<https://doi.org/http://dx.doi.org/10.31851/jmksp.v2i2.1477> 